\title{
The Question Asking Skills of Preschool Teacher Candidates: Turkey and America Example
}

\author{
D. Neslihan Bay \\ Correspondence: D. Neslihan BAY, Faculty of Education, Eskisehir Osmangazi University, Odunpazari, Eskisehir, \\ Turkey
}

Received: August 27, 2015 Accepted: September 30, 2015 Online Published: October 14, 2015

doi:10.11114/jets.v4i1.1141 URL: http://dx.doi.org/10.11114/jets.v4i1.1141

\begin{abstract}
Question asking is an important skill that teachers should use during class activities. Teachers need to get used to this ability while they are teacher candidates. The aim of this research is to identify the cognitive taxonomy and the structure of the questions asked by the candidate of preschool teachers and to compare the questioning skills of preschool teacher candidates in Michigan, USA and Turkey. The participants were selected from people who are both senior students and have preschool teacher experience. The participant teacher candidates of the present study have stated that they have not taken a questioning skill course, but the topic was taught in some of the courses. In this research, we used document review, a kind of qualitative research technique. Document evaluation was based on question formation forms. The candidate of preschool teachers were asked to write questions on "Question Formation Form". The questions asked by participant teacher candidates were analyzed and the percent frequency tables of the questions are given. As a result, we observed that teacher candidates have mainly asked questions in the first three levels of the taxonomy. Our results also showed that the teacher candidates from Turkey have rarely asked application questions and candidates from the US have usually asked comprehension questions. When examining structure of the questions, the teacher candidates in Turkey asked more than twice as many close-ended questions than the teacher candidates in the US.
\end{abstract}

Keywords: preschool, asking questions, structure, cognitive taxonomy

\section{Introduction}

The preschool period is a time in which children have the most curiosity and desire to discover. This is why, in this period that children ask questions and await replies frequently. During this period teachers need to know how to respond to children's questions and how to support their attention (Ceylan, Kahraman, \& Ulker, 2015). This knowledge includes teachers' ability to use skills to determine which goal oriented questions can be asked effectively. Hence, it is important to have knowledge of the purpose, type, and level of the questions that are to be asked (Cecil \& Pfeifer, 2011). The purposes of asking questions can be categorized as drawing attention, diagnosing and checking, reviewing some facts and information, managing, encouraging advanced level thinking processes, configuration of learning, redirecting, and expressing emotions. The knowledge of what kind of questions can be asked is reflected in the cognitive taxonomy Bloom composed (Borich, 2013). 
Tablo 1. Bloom's cognitive taxonomy

\begin{tabular}{|c|c|c|}
\hline $\begin{array}{ll}\text { Type of } \\
\text { Question }\end{array}$ & Responsive Behavior & Question beginnings \\
\hline Knowledge & $\begin{array}{l}\text {-Remembering facts or } \\
\text { observations } \\
\text {-Remembering definitions }\end{array}$ & $\begin{array}{l}\text {-Who } \\
\text {-What } \\
\text {-Where } \\
\text {-When } \\
\text {-Single word definitions }\end{array}$ \\
\hline Comprehension & -Explanations & $\begin{array}{l}\text { Explanation (What happened when the third goat } \\
\text { jumped over the fence?) }\end{array}$ \\
\hline Application & -Applying techniques & $\begin{array}{l}- \text { If.....then... } \\
\text {-What is the length of the room? }\end{array}$ \\
\hline Analysis & $\begin{array}{l}\text {-Stating reasons } \\
\text {-Conclusion }\end{array}$ & $\begin{array}{l}\text {-Why...? } \\
\text {-Now we are learning about whales. As a } \\
\text { conclusion, what can we say about them? }\end{array}$ \\
\hline & $\begin{array}{l}\text {-Finding evidence supporting } \\
\text { general conclusions }\end{array}$ & -What is your evidence to support? \\
\hline Synthesis & $\begin{array}{l}\text {-Problem solving } \\
\text {-Guessing } \\
\text {-Creating original product }\end{array}$ & $\begin{array}{l}\text {-How can we solve this problem? } \\
\text {-How can we improve our research? } \\
\text {-What will happen when you find it? } \\
\text {-What will happen according to your estimation? }\end{array}$ \\
\hline Evaluation & $\begin{array}{l}\text {-Expressing opinions on } \\
\text { conditions } \\
\text {-Evaluation of correctness of } \\
\text { ideas } \\
\text {-Evaluation of problem solving } \\
\text { skills } \\
\text {-Evaluation of other products and } \\
\text { artistic quality } \\
\text {-Evaluation of opinions and ideas }\end{array}$ & $\begin{array}{l}\text {-Do you agree with him/her? } \\
\text {-Do you believe that this is to best option to take? } \\
\text { Why? } \\
\text {-What is your solution for this problem? Why? } \\
\text {-Why do you think this is the best option? } \\
\text {-Which video do you like better? Why? }\end{array}$ \\
\hline
\end{tabular}

(Cecil \& Pfeifer, 2011).

Bloom (1956) generated six thinking hats, in other words, cognitive steps, which are knowledge, comprehension, application, analysis, synthesis, and evaluation. Anderson and Krathwohl (2001) reordered the taxonomy changed the definition of the synthesis step as creativity and putting it before the evaluation step. They conducted elaboration within the dimensions of the lower steps along with innovations, yet no radical change was made.

The steps of the questions used in educational environments affects the thinking levels of children. In this context, questions should be pre planned so that they reveal the knowledge of children which already exists, and so that they improve their skills. Children's thinking skills are detected; and afterwards the development of children is supported by tending towards higher level questions. If students' existing knowledge cannot be revealed, students will remain at the remembering stage, because the question refers to a scheme which already exist in the child, even if the question being asked is characterized as a higher-level question (Sanders, 1966; Goodwin et al.; 1983; Morgan \& Saxton, 1991; Storey, 2004). Consequently, questions should be prepared according to thinking steps and children's developmental stages (Storey, 2004).

Remembering and knowledge questions are required for teachers to determine the knowledge level of the child. Questions which support the thinking skills of children can be planned after the knowledge level is determined. Asking questions limited only to the knowledge level will restrict children's cognitive processes (Hunkins, 1972; Carin et al.. 2005). Teachers can ask questions from all levels, provided that they know all of the levels of the cognitive taxonomy well. Each step in the taxonomy has more complex thinking processes than far more steps, in terms of skills. The taxonomy's first three steps, which are knowledge, comprehension, and application, can be grouped as the lower-cognitive level; and last three steps which are analysis, synthesis and evaluation can be grouped as higher-cognitive level (Bloom et al.., 1956; Sanders, 1966; Goodwin et al., 1983; Wilen, 1991; Storey, 2004). After revealing the existing knowledge of children and their comprehension and application skills, teachers can develop the analysis, synthesis and evaluation processes, which are regarded as higher level thinking processes (Cotton, 1989; Brown \& Wragg, 1993; Storey, 2004; Warner \& Sower, 2005). Teachers need to have an aim when asking questions referring to each level. Lower level questions are asked in order to evaluate the child and to determine the strong and weak sides of the child, while higher level questions should be asked to develop problem solving skills and to support deep critical thinking (Hunkins, 1972; Goodwin et al., 1983; Morgan \& Saxton, 1991; Ellis, 1993; Filippone, 1998; Storey, 2004).

The teacher needs to plan how to ask questions referring to each level in advance according to the syllabus so as to ask 
questions, at the desired level. In accordance with the prepared plan, the questions to be asked during a classroom activity should be written (Brown \& Wragg, 1993). For instance, a teacher who is showing a picture to children should determine the questions by writing them beforehand as follows:

Knowledge: What do you see in this picture?

Comprehension: How do we call places like this?

Application: Do you know anywhere else like this picture?

Analysis: Why are there so many police officers in this picture?

Synthesis: What would happen if there weren't any police officers?

Evaluation: Would you prefer to live in a big city like this or in a small town? Why? (Morgan \& Saxon, 1991)

Also, the teacher should arrange her materials supporting the questions in alliance with the designated level of acquisition (Hunkins, 1972). The ability to arrange questions according to the taxonomy not only provides support for children according to their developmental level, but also develops higher level thinking skills as well (Doganay \& Unal, 2006; Buyukalan, 2007).

Apart from cognitive taxonomy, questions are also categorized according to their structures. Yes/no questions and single-word answer questions are classified as close-ended questions, while questions which require long answers and explanations are classified as open-ended questions (Bradtmueller \& Egan, 1983; MacNaughton \& Williams, 2004; De Rivera et al., 2005; Acıkgoz, 2006; Jonhston et al., 2007). While close-ended questions require knowledge level answers, open-ended questions require answers which lead children to thinking and expressing their ideas. (Carin et al., 2005) studies show that open-ended questions frees children's thoughts and motivate them to give longer answers by developing their thinking skills (Wasik \& Bond, 2001; Van Kleeck et al., 2006; Wasik, Bond \& Hindman, 2006; Zucker et al., 2009). As well as having the ability of using the steps of the cognitive taxonomy, it is important for teachers to know and use the structures of the questions.

Limited research has been done to investigate the question-asking skills of preschool teacher and preschool preservice teachers. Pre-existing researches on teachers' question asking skills indicate a tendency of asking lower level questions in teachers (Gall, 1970; Gall, 1984; Duster, 1997; Sultana \& Klecker, 1999; Storey, 2004; Baysen, 2006; Blatchford \& Mani, 2008, Bay \& Alisinanoglu, 2012). In fact, teachers need to plan their questions by considering the level of children and by supporting them (Morgan \& Saxton, 1991; Storey, 2004; Bay \& Alisinanoglu, 2012). This state of teachers indicates their insufficient knowledge of how to ask questions, as well as insufficient acquisition of question asking knowledge from their undergraduate program. In our country, Turkey, research done related to teachers' and teachers' candidate question-asking skills is quite limited; thus there is need to conduct research concerning this issue (Bay \& Alisinanoglu, 2012; Bay \& Alisinanoglu, 2013). This research has become more of an issue because it draws attention to the necessity of question-asking skills of candidate preschool teachers. Although there are no specific courses in undergraduate preschool teaching programs in universities, where question-asking skills should be acquired, some courses include question-asking skills as a subject. Whether this education provided by undergraduate programs equips preschool teachers with sufficient question asking skills or not has been the motivation of this research. Likewise, in the state of Michigan in the USA, pre-service preschool teachers take courses mainly on question asking skills as a part of their undergraduate programs, and other courses help teacher candidates acquire this skill as well. The second question which acts as a source of this research is whether there is a noteworthy difference between the two groups regarding the question-asking skills of preschool teacher candidates.

Also, this research has been regarded as significant because it raises a criticism of the undergraduate programs and the efficiency of the strategies of courses these programs include.

\subsection{Objective of the Research}

The goal of this research was to present whether preschool teacher candidates in both the US and Turkey are qualified enough for preparing higher level questions for classroom activities, by seeking, answers to these questions:

1. What kind of questions do preschool teacher candidates ask in educational activities?

2. What are the differences in the way American and Turk pre-service teachers sort the questions?

\section{Method}

In this research, document review, which is a kind of qualitative research, was used. Document review involves the analysis of the written materials, which includes information about the targeted facts (Metin, 2014; Yildırım \& Simsek, 2006). The document review method was used in the examination of the question formation forms, by which teacher candidates showed their question-asking skills by applying their intellectual processes. The questions prepared by 
teacher candidates from both countries were analyzed in this research.

\subsection{Participants}

Participants were determined by a purposeful sampling method. Purposeful sampling permits in-depth study of cases, which are considered as rich sources of information (Yildirım \& Simsek, 2008). Firstly, the countries - Turkey and the USA - were identified according to purposeful sampling method. The preschool education program in Turkey, which was developed based on the analysis of the program samples adapted in the USA, is a developmental program, featuring creativity and discovery. By looking at the similarities of the programs adapted in these countries, the similarities of teachers' proficiency levels were predicted as well. In this research, two universities were determined in Turkey and the USA, which ranked in the top ten in terms of success. Michigan State University of USA is especially regarded as the best Faculty of Education among other universities' education faculties (http://colleges.usnews.rankingsandreviews.com/). Established by M.K. Ataturk, the Gazi Faculty of Education of Gazi University is one of the most successful and old-lined faculties of Turkey (http://gef.gazi.edu.tr/posts/view/title/neden-gef\%3F-4768). Therefore, these two universities, which are successful in the field of teacher education were choosen as samples. In the identification of participants from these universities, the convenience sampling method, one of the purposive sampling methods, was carried out in order to make the research practical and fast (Yıldırım \& Simsek, 2008). Participants were selected on a volunteer basis according to convenience sampling. From Gazi University and Michigan State University 14 teacher candidates who were senior students and who had completed their internship participated in the study. Seven of the teacher candidates were from the Department of Early Childhood Education of the Faculty of Education of Gazi University, and the other seven were from Michigan State University's Faculty of Human Development and Family Studies, in the Early Childhood Education Department. All of the participants were female and in the 20-25 age group, concerning their demographical properties. Neither of the universities had a course directly related to question asking skills in their undergraduate programs; however question-asking skills were taught to teacher candidates as a subject in some courses, which can be seen as a shared characteristic of Gazi and Michigan State Universities.

\subsection{Data Collection}

Receiving the opinions of five domain experts, a question writing form was structured concerning pedagogical activities which can be done in a day (leisure time, language, science, music, game, preparation to literacy). The form was translated into English and was checked by two language experts. The question writing Form was given to each teacher candidate in their one-on-one interviews, and the teacher candidates were asked to write the questions which they can ask children. The teacher candidates spent time between 15 minutes and 30 minutes to write their questions.

\subsection{Data Analysis}

The questions written on the Question Forms by teacher candidates were coded in terms of cognitive taxonomy (from a knowledge to an evaluation step) and structure (open-ended/ close-ended) in order to determine how teachers ask the kinds of questions this coding system was designed to measure.

In coding the questions written by the teacher candidates according to the cognitive taxonomy, the keywords assigned to each cognitive level as designated by Bloom (1956) and the cognitive levels in the related body of literature were defined as follows.

Table 2. Definitions used in coding the cognitive taxonomy of the questions

\begin{tabular}{|c|c|}
\hline Evaluation & Requires children to make judgments and reach conclusions using specific standards \\
\hline Synthesis & $\begin{array}{l}\text { Requires children to collect information pieces to form complete information, and requires them to think of different } \\
\text { solutions for a problem }\end{array}$ \\
\hline Analysis & Requires children to understand the complex and tangled pieces of something and how they cluster \\
\hline Application & Requires children to adopt their knowledge to new situations and transfer their knowledge \\
\hline Comprehension & $\begin{array}{l}\text { The ability to re-express, transform, paraphrase, translate and guess the material depending on one's previous } \\
\text { knowledge }\end{array}$ \\
\hline Knowledge & Requires children to remember their previous knowledge and present their existing knowledge \\
\hline
\end{tabular}

(Bloom et al.., 1956; Cecil \& Pfeifer, 2011; Bay \& Alisinanoglu, 2012).

The coding was done by giving each cognitive level a number ranging from 1 to 6 . The questions written by teachers according to their daily lesson plans were coded according to Bloom's cognitive taxonomy. Questions relating to the knowledge step were coded as 1 point, comprehension questions were coded as 2 points; application questions were coded as 3 points; analysis questions were coded as 4 points; synthesis questions were coded as 5 points and evaluation questions were coded as 6 points.

Open ended questions investigate the thinking processes of children and require children to share their assumptions, knowledge, imagination, and emotions with adults or other children in general (Klein, et al., 2000). In other words, 
open-ended questions require children to make explanations (Sonmez, 2007). Therefore, preschool teachers consider an open-ended question as a question which may have several answers (Morgan \& Saxton, 1991; Carin et al., 2005). According to Bloom's Taxonomy, higher level questions (analysis, synthesis, and evaluation) and questions which may have several answers and require explanation are considered open-ended questions. Closed-ended questions, which are generally yes/no questions, are asked to identify or remind one of specific facts or knowledge (Storey, 2004, MacKay, 1997). This is why close-ended questions generally have one-word answers (Sonmez, 2007).

In the analysis of questions written by the teacher candidates the table below was prepared based on the body of literature.

Table 3. Definitions used in coding structure of the questions

\begin{tabular}{ll}
\hline Open-ended Questions & Questions which require explanation analysis, synthesis, and evaluation questions \\
\hline Closed-ended Questions & Questions which require one-word answers and yes/no questions \\
\hline
\end{tabular}

(MacNaughton \& Williams, 2004; Carin et al., 2005; Bay \& Alisinanoglu, 2013)

Questions were coded according to their structures as well. Open-ended question were coded as 2 points and close-ended questions were coded as 1 point.

In qualitative research in order to provide internal validity to the data, in other words to assure persuasiveness, the research needs to be approved by other researchers (Metin, 2014; Buyukozturk, 2008). The questions which the teacher candidates asked were coded by an expert in terms of cognitive taxonomy and structure. In the comparison of coding, different coding styles were detected, and encoder reliability was calculated of $93 \%$. Different codes were discussed, and a conclusion was reached (Tavsancil \& Aslan, 2001). That the encoder reliability was $93 \%$ shows that the coding was reliable.

\section{Findings}

Two hundred twenty three questions were analyzed; they were written by the teacher candidates on the form, which included the materials and acquisitions of the activities.

The findings on the first question (what kind of questions do teacher candidates ask in terms of educational activities?) are given in table 4 with frequency percentages in reference to their cognitive taxonomy and structures.

Table 4. Percentage and frequency distribution of the questions in terms of cognitive taxonomy

\begin{tabular}{|c|c|c|c|c|c|c|c|c|c|c|c|c|c|c|}
\hline & \multicolumn{2}{|c|}{ Know. } & \multicolumn{2}{|c|}{ Comp. } & \multicolumn{2}{|c|}{ Appl. } & \multicolumn{2}{|c|}{ Anal. } & \multicolumn{2}{|c|}{ Synt. } & \multicolumn{2}{|c|}{ Eval. } & \multicolumn{2}{|c|}{ Total } \\
\hline & $\mathrm{f}$ & $\%$ & $\mathrm{f}$ & $\%$ & $\mathrm{f}$ & $\%$ & $\mathrm{f}$ & $\%$ & $\mathrm{f}$ & $\%$ & $\mathrm{f}$ & $\%$ & $\mathrm{f}$ & $\%$ \\
\hline $\mathrm{R}^{\mathrm{T}}$ & 35 & 38 & 15 & 16.3 & 0 & 0 & 12 & 13 & 17 & 18.5 & 13 & 14.1 & 92 & 100 \\
\hline U & 19 & 14.5 & 67 & 51.1 & 12 & 9.2 & 9 & 6.9 & 13 & 9.9 & 11 & 8.4 & 131 & 100 \\
\hline
\end{tabular}

In table 4, important were achieved upon evaluating the percentages of th questions asked by teacher candidates. With the ratio of 38 percent, teacher candidates in Turkey asked the most knowledge questions. Following that, they asked synthesis level questions the most (18.5\%). A significant outcomes in the study, teacher candidates in Turkey did not ask any application level questions. Compared groups, it was seen that differences in this rate. On examining the US candidates' questions, it was seen that they asked comprehension questions the most (51.1\%). The second most asked questions were at the knowledge level (14.5\%). The least asked level was analysis, at $6.9 \%$. The similarity of observations in the both groups; they highly asked questions in the first three levels of the taxonomy.

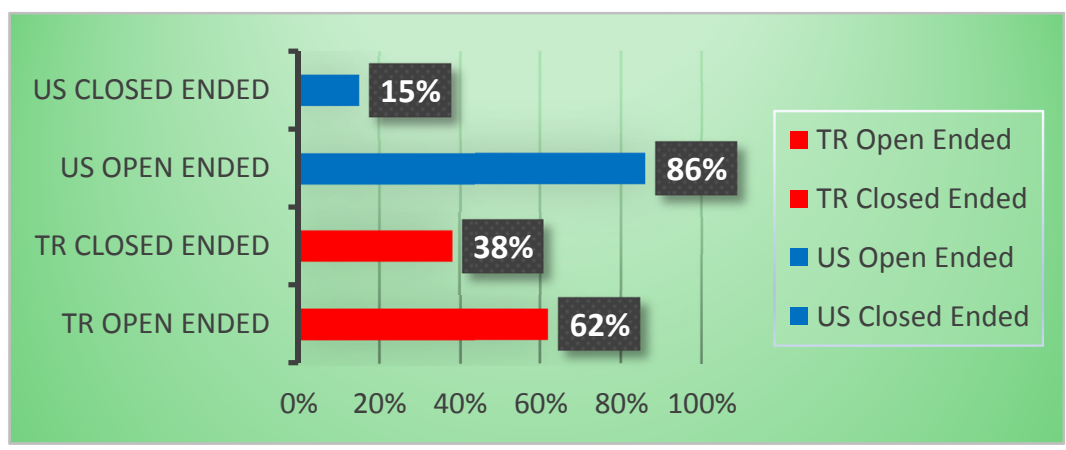

Figure1. Structure of the questions

In graphic 1 , on the structure of the questions, the knowledge level questions asked by the Turkish teacher candidates were coded as close-ended questions, and while $38 \%$ of the questions were assessed as close-ended, the remaining $62 \%$ of the questions were coded as open-ended questions. While the close-ended questions of the US teacher candidates 
were assessed as $14.5 \%$ with the same rate as their knowledge level questions, $85.5 \%$ of the questions were open-ended questions. Turkish participants wrote 92 questions and US participants wrote 131 questions. It is seen that US participants wrote 39 more questions. In other words, the teacher candidates of the US wrote $1 / 3$ more than the teacher candidates of Turkey. Questions which were written in perspective of objectives and materials by teachers were coded according to the cognitive taxonomy and structure.

The second question of the research, "What are the differences in the sorting of the questions written by teacher candidates who are in the preschool teaching undergraduate program?" was answered by making comparisons of percentages. It was seen that while teacher candidates in Turkey asked $38 \%$ of their questions at the knowledge level, teacher candidates in the US asked $14.5 \%$ of their questions at the knowledge level. According to the results, teacher candidates in Turkey asked twice as many knowledge questions. The most distinct difference in the rates of questions was seen at the comprehension level. Teacher candidates in US asked $51.1 \%$ of their questions at the comprehension level, while the ones in Turkey asked $16.3 \%$ of their questions at the comprehension level. Another visible difference is on the application level. The teacher candidates in Turkey asked no application level questions, whereas $9.2 \%$ of the questions asked by the teacher candidates in the US were at the application level. For the last three steps of the taxonomy, Turkish candidates asked twice as many analysis and synthesis questions as the US teacher candidates did. Turkish participants asked more questions at the evaluation level as did the US participants as well.

Upon evaluating the differences of questions in terms of structure, it was seen that the teacher candidates in Turkey asked more than twice as many close-ended questions than the teacher candidates in the US (38\% - $14.5 \%)$.

\section{Conclusion and Discussion}

This research were done in order to reveal what kinds of questions preschool teacher candidates ask, and the differences were in the questions asked by the two groups. With these objectives, the teacher candidates were asked to write questions on the form, which was generated in consultations with experts; and the teacher candidates were to be senior students and were doing their teaching practice, asking criteria of this research. That the teacher candidates were about to graduate and start their teaching career is important for the results of this research.

When examining the findings, it was seen that the participants from both countries asked questions mostly at the first three steps of the taxonomy, representing lower level thinking skills. Participants from the US asked mainly comprehension level questions, and participants from Turkey asked mainly knowledge level questions both types being at the first levels of the taxonomy.

The Turkish participants asked no questions at the application level, whereas the US teacher candidates asked application level questions at the rate of $9.2 \%$. On analyzing the last three steps, which symbolize higher level thinking skills, it was seen that the Turkish teacher candidates asked more questions at each of these three levels. That the questions asked by the teacher candidates from both countries were predominantly at the first three levels of the taxonomy, which are seen as lower cognitive levels, shows that these teachers do not know how ask questions at the analysis, synthesis, and evaluation steps. The results of the research correspond to the research done on teachers and teacher candidates, which have resulted in the conclusion that teachers tend to ask lower level questions (Buraldi, 1998; Aydemir \& Ciftci, 2008; Aslan \& Guneyli, 2008; Aslan, 2009; Baysen, 2006; Gufta \& Zorbaz, 2008; Ulger, 2003). However, each step of the taxonomy reveals different thinking processes (Bloom et al., 1956; Sanders, 1966; Hunkins, 1972). Therefore, asking questions at each level is necessary (Storey, 2004; Buyukalan Filiz, 2009; Aslan, 2011; Bay, 2011). In researches on equipping teachers with question asking skills appropriate to each level of the taxonomy, it has been asserted that educational practices are effective concerning question asking skills (Barnette et al., 1994; Savage, 1998; Wasik \& Bond, 2001; Buyukalan Filiz, 2002; Storey, 2004; Wasik et al., 2006; Wong, 2006; Aslan, 2011; Bay, 2011).

As can be seen here neither of the countries provides their students with proper courses mainly on the question asking skills that a teacher should acquire in his/her undergraduate programs. Also, it can be seen that it is not adequate for teacher candidates to learn to teach question asking skills only with a limited part of a course acquire this skill fully. Research indicates that teachers who have received education on asking questions of high quality show significant improvement and encourage their students to reveal their potential (Barnette et al., 1994; Savage, 1998; Büyükalan Filiz, 2002; Storey, 2004; Wong, 2006; Bay, 2013).

Upon studying the case in his research, Bay (2011) provided training on question asking skills for teachers, and then checked the question asking skills levels of teachers again. On providing training for teachers, it was seen that teachers are qualified with question asking skills, and they are able to ask questions on the last three steps of the taxonomy, and as well as open-ended questions. After this training for teacher candidates, the rise of the rates of questions compared to the previous training shows the efficacy this approach to training. As a result of this, research which is done in the light of other research that indicates that this skill can be acquired with direct training, the reason that some teacher 
candidates cannot show the ability to ask questions at each level of the taxonomy is related to the fact that that they have not received direct education on this skill.

Another important result of this research is that the results on the structure of the questions show that the ratio of close-ended questions is high especially for teacher candidates in Turkey. Similarly, other researches done on the structures of questions asked by teachers has revealed that close-ended questions are asked more frequently (Storey, 2004; Blatchford \& Mani, 2008; Tsung-Hui \& Wei-Ying, 2008; Lee, 2010; Bay \& Alisinanoğlu, 2013). Regarding the comparisons of the result in the two countries, it was seen that teacher candidates in Turkey asked twice as many close-ended questions. However, open-ended questions enable children to widen the existing schemes in their minds, and thus help them give longer, more complex, and variable answers (Johnston et al., 2007; De Rivera et al, 2005; Storey, 2004; Paterson, Dowden, \& Tobin, 1999). Consequently, open-ended questions lead children to high level thinking processes and improve their using solution thinking skills in the event of facing problems (Duster, 1997, Jonhston et al., 2007; Klein et al., 2000). It is also known that open-ended questions support language development, because these questions allow children to express themselves (Wasik \& Bond, 2001). To support children's development in their early years, open-ended questions need to be known by teachers and used effectively.

Just as at the other stages of education, in the preschool stage, in which child development is at its highest rate, question asking is an important skill that every teacher should be equipped with. In the conclusions of the research, it was seen that neither of the countries' participants could use this skill effectively. The results of this research show that teacher candidates who do not receive courses solely on question-asking skills lack these skills. Teachers' need of question asking skills should not be ignored, because these questions support children's intellectual, language, and social development. Educational support should be provided to meet this need; and practical lessons which help teacher candidates acquire the skill to use the steps of the taxonomy and question-forming should be included in undergraduate programs.

\section{Limitations of the Research}

Because only two universities were included in the research and because there were of only 14 senior teacher candidates and all of the participants were female, the research has limitations. The research needs to be extended to a wider group of teacher candidates, and the research need to be done in education faculties of different universities.

\section{References}

Açıkgoz, K. (2006). Aktif öğrenme. İzmir: Biliş Yayıncılık.

Anderson, L. W., \& Krathwohl, D. R. (Eds.). (2001). A taxonomy for learning, teaching and assessing: A revision of Bloom's Taxonomy of educational objectives: Complete edition. New York: Longman.

Aslan, C. (2011). Soru sorma becerilerini geliştirmeye dönük öğretim uygulamalarının öğretmen adaylarının soru oluşturma becerilerine etkisi. Education, 36(160), 236-249.

Aslan, C., \& Güneyli, A. (2008). Türk dili ve edebiyatı öğretmen adaylarının öğretim ortamlarında karşılaştıkları sorunlara yönelik görü̈şleri. I. Uluslararası Türkçe Eğitimi ve Öğretimi Sempozyumu Bildiri Kitapçı̆̆ı, Doğu Akdeniz üniversitesi, Kuzey Kıbrıs Türk Cumhuriyeti, 85-109.

Aydemir, Y., \& Çiftçi, Ö. (2008). Edebiyat öğretmeni adaylarının soru sorma becerileri üzerine bir araştırma. Yüzüncü Yll Üniversitesi Ĕ̈itim Fakültesi Dergisi, 5(2), 103-115.

Barnette, J., Orletsky, S., \& Sattes, B. (1994). Evaluation of Teacher Classroom Questioning Behaviors. Office of Educational Research and Improvement. Washington, ERIC Education Resources Information Center. (ED 377 188).

Bay, D. N. (2011). Okul öncesi ögretmenlerine verilen soru sorma becerisi öğretiminin etkisinin incelenmesi. Doktora Tezi, Gazi Üniversitesi Eğitim Bilimleri Enstitüsü, Ankara.

Bay, D. N., \& Alisinanoğlu, F. (2012). The effect of teaching questioning skills curriculum applied to preschool education teachers on cognitive taxonomy of teachers' questions. Mersin Üniversitesi Ë̆itim Fakültesi Dergisi, 8(3), 80-93.

Bay, D. N., \& Alisinanoğlu, F. (2013). The effect of teaching questioning skills given to preschool teachers on structure of teachers' questions. Journal of Theoretical Educational Science, 6(1), 1-39. (ISSN: 1308-1659)

Baysen, E. (2006). Öğretmenlerin sınıfta sordukları sorular ile öğrencilerin bu sorulara verdikleri cevapların düzeyleri. Kastamonu Eğitim Dergisi, 14(1), 21-28.

Blatchford, I., \& Mani, L. (2008). Would you like to tidy up now?' An analysis of adult questioning in the English foundation stage. Early Years, 28(1), 5-22. http://dx.doi.org/10.1080/09575140701842213

Bloom, B. S., Engelhart, M. D., Furst, E. J., Hill, W. H., \& Krathwohl, D. R. (1956). Taxonomy of educational objectives: 
The classification of education goals. Handbook I: Cognitive domain (Vol. 1). New York, NY: David McKay Company.

Borich, G. D. (2013). Effective teaching methods: research- based practice (Eighth edition). River, NJ: Pearson Education.

Bradtmueller, W. G., \& Egan, J. B. (1983). To question or not to question: That seems to be the question. Journal of the Association for the Study of Perception, 18(2), 23-28 (ED248492).

Brown, G., \& Wragg, E. C. (1993). Questioning. New York: Routledge

Brualdi, A. C. (1998). Classroom questions. Catholic University of America, Department of Educations, ERIC Clearinghouse on Assessment and Evaluation.

Buyukalan, F. S. (2002). Soru-cevap yöntemine ilişskin ögrretimin öğretmenlerin soru sorma düzeyi ve tekniklerine etkisi. Yayımlanmamış Doktora Tezi, Ankara: Gazi Üniversitesi Eğitim Bilimleri Enstitüsü.

Buyukalan, F. S. (2007). Öğretmenler için soru sorma sanatı. Ankara: Nobel.

Buyukalan, F. S. (2009). Soru cevap yöntemi eğitiminin öğretmenlerin soru sorma bilgisi ve soru sorma tekniklerine etkisi. Sosyal Bilimler Enstitüsü Dergisi, (3), 167-195.

Carin, A., Bass, J., \& Contant, T. (2005). Methods for teaching science as inquiry. New Jersey: Pearson Merrill Prentice Hall.

Cecil, L. N., \& Pfeifer, J. (2011). The art of inquiry questioning strategies for K-6 classrooms. MB Canada: Winnipeg, MB Canada: Portage \& Main Press.

Ceylan, S., Kahraman, Ö. G., \& Ülker, P. (2015). Çocukların meraklarına ilişkin annelerin ve öğretmenlerin düşünceleri: Bilim kavramı. Karabük Üniversitesi Sosyal Bilimler Enstitüsü Dergisi, 5(1), 1-16. http://dx.doi.org/10.14230/joiss108

Cotton, K. (1989). Classroom questioning. School İmprovement Research Series III, ERIC Education Resources Information Center. (ED 312 030).

De Rivera, C., Girolametto, L., Greenberg, J., \& Weitzman, E. (2005). Children's responses to educators 'questions in day care play groups. American Journal of Speech-Language Pathology, 14(1), 14-26. http://dx.doi.org/10.1044/1058-0360(2005/004)

Doganay, A., \& Unal, F. (2006). Eleştirel düşünmenin öğretimi. İçerik türlerine dayalı ögrretim. (Ed. A. Şimşek) Ankara: Nobel.

Duster, S. (1997). Classroom questioning: How teacher uses it to promote creativity and higher level thinking. Master of Art Education, the Faculty of Pacific Lutheran University, America.

Ellis, K. (1993). Teacher questioning behavior and student learning: What research says to teachers? Paper presented at the 1993 Convention of the Western States Communication Association, ERIC Education Resources Information Center (ED 359 572).

Filippone, M. (1998). Questioning at the elementary level. Master's Thesis, Kean University. ERIC Education Resources Information Center (ED 417 431).

Goodwin, S., Sharp, G., Cloutier, E., \& Diamond, N. (1983). Effective classroom questioning. East Lansing, MI: National Center for Research on Teacher Learning, ERIC Education Resources Information Center. (ED 285 497).

Gufta, H., \& Zorbaz, K. Z. (2008). İlköğretim ikinci kademe Türkçe dersi yazılı sınav sorularının düzeyleri üzerine bir değerlendirme. Çukurova Üniversitesi Sosyal Bilimler Enstitüsü Dergisi, 17(3), 205-218.

Hunkins, F. P. (1972). Questioning strategies and techniques. Boston, MA: Allyn \& Bacon.

Johnston, J., Halocha, J., \& Chater, M. (2007). Developing teaching skills in the primary school. America: Open University Press.

Klein, E., Hammrich, P., Bloom, S., \& Ragins, A. (2000). Language development and science inquiry: a child-initiated and teacher-facilitated program. American Educational Research Association, ERIC Education Resources Information Center (ED 440 756).

Lee, Y. (2010). Blended teacher supports for promoting open-ended questioning in pre-k science activities. Doctor of Philosophy, University of Virginia, America.

Mackay, I. (1997). Soru sorma sanatı. (Cev. A. Bora, O. Cankocak). Ankara: İlkkaynak Kültür ve Sanat Ürünleri. 
MacNaughton, G., \& Williams, G. (2004). Teaching young chlldren choices in theory and practice. Australia: Ligare Pty. Ltd.

Morgan, N., \& Saxton, J. (1991). Teaching, questioning and learning. New York: Routledge.

Paterson, C., Dowden, C., \& Tobin, J. (1999). Interviewing preschoolers: Comparisons of yes/no and wh- questions. Law and Human Behavior, 23(5), 539-555. http://dx.doi.org/10.1023/A:1022396112719

Sanders, N. M. (1966). Classroom questions: What kinds. New York: Harper \& Row.

Savage L. (1998). Eliciting critical thinking skills through questioning. Clearing House, 71(5), 291-93. (EJ568469). http://dx.doi.org/10.1080/00098659809602727

Sonmez, V. (2007). Program geliştirmede ögretmen el kitabl. Ankara: Anı.

Storey, S. (2004). Teacher questioning to improve early childhood reasoning. Doctor of Philosophy, Department of Teaching and Teacher Education, Arizona University.

Sultana, O., \& Klecker, B. (1999). Evaluation of first year teachers lesson objectives by Bloom's taxonomy. Educational Research Association. Point Clear AL, ERIC Education Resources Information Center, 17-19, (ED 436 524).

Tavşancıl, E., \& Aslan, E. (2001). İ̧erik analizi ve uygulama örnekleri. İstanbul: Epsilon.

Tsung, H. T., \& Wei, Y. W. (2008). Preschool Teacher-child verbal interactions in science teaching. Electronic Journal of Science Education, 12(2), 1-23.

Ulger, U. (2003). İlköğretim 6, 7, 8. sınıflarda Türkçe dersi yazılı sınav soruları üzerine bir değerlendirme. Yüksek Lisans Tezi, Gazi Üniversitesi Eğitim Bilimleri Enstitüsü, Ankara.

Warner, L., \& Sower, J. (2005). Educating young children. Boston: Pearson Education.

Wasik, B. A., \& Bond, M. A. (2001). Beyond the pages of a book: İnteractive book reading and language development in preschool classrooms. Journal of Educational Psychology, 93(2), 243-250. http://dx.doi.org/10.1037//0022-0663.93.2.243

Wasik, B. A., Bond, M. A., \& Hindman, A. (2006). The effects of a language and literacy intervention on Head Start children and teachers. Journal of Educational Psychology, 98(1), 63-74. http://dx.doi.org/10.1037/0022-0663.98.1.63

Wilen, W. (1991). Questioning skills for teachers. What research says to the teacher? (Third Edition). Washington, DC: National Education Association, ERIC Education Resources Information Center. (ED 332 983).

Wong, A. (2006). Dialogue engagements: A space for early chlldhood educators to talk, listen and study documentation. The Thesis Submitted to The Faculty of Graduate Studies, Graduate Program in Education York University, Toronto.

Yıldırım, A., \& Şimşek, H. (2008). Sosyal bilimlerde nitel araştırma yöntemleri. Ankara: Seçkin.

\section{$(\mathrm{cc}) \mathrm{EY}$}

This work is licensed under a Creative Commons Attribution 3.0 License. 